\title{
ANALISIS PERBEDAAN GENRE GAME PADA GOOGLE PLAYSTORE MENGGUNAKAN PARAMETER TRACY FULLERTON
}

\author{
Dhimas Adi Satria ${ }^{1}$, Ema Utami ${ }^{2}$, Emha Taufiq Luthfi ${ }^{3}$ \\ Teknik Informatika, Magister Teknik Informatika \\ Universitas Amikom Yogyakarta \\ Jl. Ring Road Utara, Condong Catur, Sleman, Yogyakarta \\ dhimasadisatria $a$, gmail.com ${ }^{1}$, emma $a$, nrar.net $^{2}$, emhataufialuthfi $a$,amikom.ac.id ${ }^{3}$
}

\begin{abstract}
Game is one of the entertainment that attracted many people. Not seeing her age or profession, anyone is happy to play the game. The development of Android became the easiest operating system in the world. The number of games provided on Google Playstore is largely classified as a free game that anyone can download. This study aims to create a game design created by Tracy Fullerton, by developing the right variables in every genre of games available on Google Playstore. It is expected that each genre has characteristics as well as a benchmark of data for developers and game designers to create more varied games.
\end{abstract}

Keyword: Android, Design, Game, Tracy Fullerton, Google.

Game merupakan salah satu hiburan yang diminati banyak orang. Tidak melihat umur ataupun profesinya, siapa saja senang untuk bermain game. Perkembangan Android menjadi sebuah sistem operasi telepon pintar yang paling banyak digunakan di dunia. Pertumbuhan jumlah game yang disediakan pada Google Playstore sebagian besar tergolong sebagai game gratis yang bisa diunduh oleh siapa saja. Penelitian ini bertujuan melakukan evaluasi terhadap struktur desain game yang dibuat oleh Tracy Fullerton, dengan mengembangkan variable yang diuji pada setiap genre game yang ada pada Google Playstore. Diharapkan setiap genre memiliki karakteristik dan kelemahan sebagai patokan data bagi para developer dan desainer game untuk menciptakan game yang lebih variatif.

Kata Kunci : Android, Desain, Game, Tracy Fullerton, Google

\section{Latar Belakang Masalah}

Game didefinisikan sebagai "sebuah aktifitas menyelesaikan masalah, yang dilakukan dengan pendekatan bermain atau santai (playful)" (Schell, 2008). Android merupakan salah satu operating system (OS) dalam smartphone yang berbasis Linux yang di kembangkan oleh Google inc pada tahun 2005. Hingga bulan agustus 2017 android telah menguasai 85,1\% dari seluruh pengguna perangkat mobile di seluruh dunia (Statista, 2017). Tidak heran perkembangan aplikasi dan game di android sangatlah pesat dan semakin beragam.

Game Design adalah suatu proses dari mengimajinasikan suatu ide game, mendefinisikan bagaimana suatu game bekerja, mendeskripsikan elemen-elemen yang membangun game tersebut (dari segi konsep, fungsi, artistik dan segi-segi lainnya) dan mengantarkan informasi tentang ide game tersebut kepada tim yang membangun game (Ernest, 2010). Sedangkan menurut Schell, game desain adalah aksi yang menentukan bagaimana seharusnya sebuah game (Schell, 2008). Sehingga merancang sebuah desain game sangat berpengaruh terhadap perkembangan dan tujuan dari diciptakannya game tersebut.

Pada penelitian sebelumnya, Tracy Fullerton telah menjabarkan sebuah game menjadi elemen elemen penting. Elemen ini merupakan metode penjabaran yang sangat tepat dan mudah untuk di aplikasikan, dikarenakan yang didalamnya mudah dipahami, dipelajari, dan sangat lengkap dalam melakukan pendekatan terhadap perancangan desain dari sebuah game. 
Penelitian ini akan mengembangkan elemen yang sudah ditemukan dengan menambahkan variable secara kuantitatif nilai dengan menggunakan skala Likert dan mengujinya terhadap genre game yang ada pada Google Playstore. Sehingga akan ditemukan elemen mana yang dominan pada setiap genre, serta elemen yang tidak dominan pada genre tersebut.

\section{Metodologi Penelitian}

\subsection{Game}

Salah satu jenis aktifitas bermain yang dilakukan dalam konteks berpura-pura namun terlihat seperti realitas, yang mana pemainnya memiliki tujuan untuk mendapatkan satu kemenangan serta dilakukan sesuai dengan aturan permainan yang telah dibuat. (Adam \& Rolling, 2010). Pembagian game berdasarkan jenis (Genre) permainannya (Google Playstore, 2017) adalah : Action, Advanture, Arcade, Board, Card, Casino, Casual, Educational, Music, Puzzle, Racing, Role Playing, Simulation, Sports, Strategy, Trivia, Word. Penelitian ini mengambil 5 sample game secara random pada setiap ganre, sehingga akan didapatkan total 85 game yang terbagi kedalam 17 genre game.

\subsection{Tracy Fullerton}

Tracy Fullerton telah membuat sebuah parameter pendekatan Desain game yang mengelompokan kedalam struktur dasar sebuah game (Fullerton, 2014). Dalam bukunya yang berjudul "Game Design Workshop: A Playcentric Approach to Creating Innovative Games", membagi unsur dalam mendesain game sebagai berikut.

Formal Elemen :

1. Player (Pemain) : Merupakan pendekatan terhadap pemain, meliputi jumlah pemain, kemampuan pemain, dan kekuatan dari pemain.

2. Objectives (tujuan) : Merupakan sebuah tujuan dari game diciptakan bisa dengan mengalahkan musuh, menyelesaikan stage, menyelamatkan sandera, dll.

3. Procedure (Prosedur) : Meliputi prosedur bermain dalam game, dimulai dari start memulai awal bermain hingga berakhirnya game.

4. Rules (aturan) : Merupakan aturan, batasan, dan larangan yang berlaku dan tidak boleh dilanggar dalam sebuah game. Rules juga termasuk dalam batasan bermain game seperti dilarang jatuh kejurang, dilarang menyerang teman, dll.

5. Resources (Sumber Daya) : Merupakan sumber daya yang dibutuhkan pemain dalam bermain game seperti nyawa tambahan, makanan, senjata, dll.

6. Conflict (Masalah) : Merupakan pokok permasalahan yang akan dihadapi pemain di dalam game yaitu musuh dan hambatan - hambatan yang harus di selesaikan.

7. Boundaries (Batasan) : Meliputi area ataupun arena bermain dalam game, yaitu batasan antar dunia game dan dunia luar game.

8. Outcome (Hasil) : Merupakan hasil apa yang di dapat dalam bermain game seperti nilai tertinggi ataupun waktu tercepat selama bermain game.

Dramatic Elemen :

1. Challenge (Tantangan) : Merupakan tantangan yang harus dilalui pada setiap tahap atau stage, tantangan yang baik akan dibuat semakin meningkat seiring bertambahnya kemampuan player dalam bermain game tersebut.

2. Play (Pola Bermain) : merupakan pola permainan yang dilakukan pada sebuah game. 
3. Premise (Dasar/Landasan) : Merupakan dasar tujuan dari game diciptakan, bisa juga untuk mengupas proses dalam bermain game.

4. Character (Karakter) : Meliputi sejarah dan kuatnya sebuah karakter/tokoh dalam sebuah game, sehingga karakter tersebut sangat berpengaruh besar terhadap jalannya game.

5. Story (Cerita) : Dalam beberapa game terdapat unsur cerita, sehingga berujung pada game dimulai.

6. World Building (Dunia Game) : Merupakan skenario dari game diciptakan, sama halnya dengan film fiksi, bagaimana membuat dunia sendiri pada sebuah game.

7. The Dramatic Arc (Plot) : Merupakan plot plot tersendiri seperti halnya scene / adegan pada film, plot tersebut bisa dilakukan dengan melawan raja biasa hingga raja terakhir.

\subsection{Skala Likert}

Pada penelitian ini menggunakan selected sample dan menggunakan teknik pengambilan sampel untuk proses justifikasi pakar dengan pertimbangan tertentu yang disebut dengan teknik sampling purposive (Sugiyono, 2012). Roscoe (1975) dalam Sekaran (2006) memberikan salah satu acuan dalam pengambilan sampel yang dapat digunakan untuk penelitian. Pada penelitian ini, peneliti akan menggunakan 6 sample kuat yang memiliki kriteria dan berpengaruh besar terhadap dunia game, diantaranya yaitu Ahli/Pakar dibidang game, Developer/pengembang game, dan desainer/perancang game.

Setiap sample akan melakukan penilaian dengan skala likert dengan skor Sangat baik bernilai 5, Baik bernilai 4, cukup bernilai 3 Buruk bernilai 2 dan Sangat buruk bernilai 1 seperti pada Tabel 1

Tabel 1 Kriteria Penilaian Skala Likert

\begin{tabular}{|c|c|}
\hline Variable & Keterangan \\
\hline 5 & Sangat Baik \\
\hline 4 & Baik \\
\hline 3 & Cukup \\
\hline 2 & Buruk \\
\hline 1 & Sangat Buruk \\
\hline
\end{tabular}

Setiap sample pada parameter tracy fullerton akan dihitung secara kuantitatif, dimana jumlah dari setiap unsur akan ditentukan menggunakan variable pada Tabel 1

\section{Model Penelitian}

\subsection{Model Pengujian}

Setiap pengujian yang dilakukan pada penelitian ini akan di lakukan rekap pada Tabel 2 Dimana setiap paremeter yang diuji akan dilakukan penilaian skala likert dan keterangan visual pengujian. Namun Tabel 2 hanyalah tabel data mentah yang hanya dapat meneliti satu buah game saja. Untuk menguji berbagai game dan genre maka peneliti akan membuat tabel yang mempermudah dalam mempelajari pengujian. 
Tabel 2. Pengujian sebuah Game I

\begin{tabular}{|c|c|c|c|c|c|c|c|}
\hline \multirow{2}{*}{$\begin{array}{c}\text { Parameter } \\
\text { Pengujian Tracy } \\
\text { Fullerton }\end{array}$} & \multicolumn{5}{|c|}{$\begin{array}{l}\text { Nilai Pengujian } \\
\text { (Skala Likert) }\end{array}$} & \multirow[t]{2}{*}{ Visual Pengujian } & \multirow[t]{2}{*}{ Keterangan Pengujian } \\
\hline & 5 & 4 & 3 & 2 & 1 & & \\
\hline Player & $\checkmark$ & & & & & 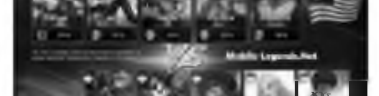 & $\begin{array}{c}\text { Game dapat dimainkan dengan } \\
\text { kuantitas } 10 \text { pemain }\end{array}$ \\
\hline Objectives & & & & $\sqrt{ }$ & & 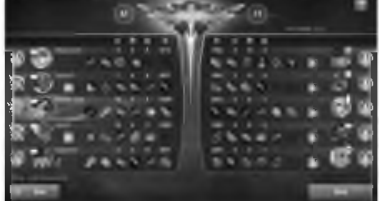 & $\begin{array}{c}\text { Nilai } 2 \text { didapat karena kuantitas } \\
\text { selain menghancurkan markas } \\
\text { musuh setiap pemain akan } \\
\text { diberikan hasil permainan }\end{array}$ \\
\hline & & & & & & & \\
\hline
\end{tabular}

Untuk mempermudah penghitungan skala liker pada sebuah genre game yang terdiri dari 5 buah game, maka peneliti membuat Tabel 3 yang lebih sederhana yang dapat memuat 5 game pada satu genre. Pada Tabel 3 angka yang diambil dalam menilai game berdasarkan pedoman pada tabel 1. selanjutnya setiap game di jumlahkan pada kolom Total Point $(\mathrm{H})$, kolom Prosentase $(\mathrm{P})$ didapatkan dari

$$
\mathrm{P}=\frac{4}{\text { jumlah gene } x \text { inax skoe likert }} \times 100 \%
$$

Tabel 3. Contoh Pengujian pada sebuah genre game (Genre Action)

\begin{tabular}{|c|c|c|c|c|c|c|c|}
\hline \multirow{2}{*}{$\begin{array}{c}\text { Elemen } \\
\text { Pengujian }\end{array}$} & \multicolumn{5}{|c|}{ Genre Game = ACTION } & \multirow{2}{*}{$\begin{array}{c}\text { Total } \\
\text { Point (H) }\end{array}$} & \multirow{2}{*}{$\begin{array}{c}\text { Prosentase } \\
\text { (P) }\end{array}$} \\
\hline & Game 1 & Game 2 & Game 3 & Game 4 & Game 5 & & \\
\hline Player & 1 & 1 & 2 & 1 & 5 & 10 & $40 \%$ \\
\hline Objectives & 1 & 1 & 2 & 1 & 2 & 7 & $28 \%$ \\
\hline Procedures & 1 & 2 & 1 & 1 & 2 & 7 & $28 \%$ \\
\hline Rules & 2 & 2 & 2 & 2 & 2 & 10 & $40 \%$ \\
\hline Resources & 1 & 3 & 1 & 1 & 3 & 9 & $36 \%$ \\
\hline Conflict & 2 & 2 & 2 & 2 & 2 & 10 & $40 \%$ \\
\hline Boundaries & 2 & 3 & 2 & 3 & 2 & 12 & $48 \%$ \\
\hline Outcome & 2 & 3 & 2 & 2 & 2 & 11 & $44 \%$ \\
\hline Challenge & 4 & 5 & 4 & 5 & 5 & 23 & $92 \%$ \\
\hline Play & 1 & 1 & 1 & 1 & 1 & 5 & $20 \%$ \\
\hline Premise & 2 & 2 & 2 & 2 & 3 & 11 & $44 \%$ \\
\hline Character & 5 & 2 & 5 & 5 & 4 & 21 & $84 \%$ \\
\hline Story & 1 & 3 & 1 & 1 & 1 & 7 & $28 \%$ \\
\hline World Building & 1 & 3 & 1 & 1 & 2 & 9 & $36 \%$ \\
\hline Dram atic Arc & 3 & 5 & 2 & 2 & 4 & 16 & $64 \%$ \\
\hline
\end{tabular}

Hasil pada Tabel 3 adalah prosentase dari 5 game dalam genre Action yang telah diuji, untuk menggabungkan hasil penelitian dari genre lain, maka peneliti membuat tabel 4 dimana menggabungkan 17 genre game terhadap parameter Tracy Fullerton yang berjumlah 15 parameter 
Tabel 4. Penggabungan pengujian pada 17 genre game dan 15 parameter hasil uji

\begin{tabular}{|c|c|c|c|c|c|c|c|c|c|c|c|c|c|c|c|c|c|c|}
\hline \multirow{2}{*}{\multicolumn{2}{|c|}{ Pengujian }} & \multicolumn{17}{|c|}{ Genre Game } \\
\hline & & \multirow{2}{*}{ 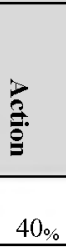 } & \multirow{2}{*}{$\frac{20 \%}{20}$} & \multirow{2}{*}{ 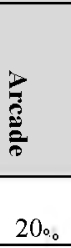 } & \multirow{2}{*}{ 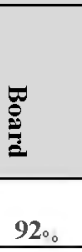 } & \multirow{2}{*}{$\frac{8}{84 \%}$} & \multirow{2}{*}{$\frac{\mathscr{E}_{0.0}^{2}}{100 \%}$} & \multirow{2}{*}{ 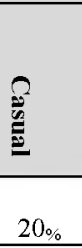 } & \multirow{2}{*}{ 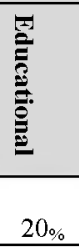 } & \multirow{2}{*}{$\frac{2}{20 \%}$} & \multirow{2}{*}{ 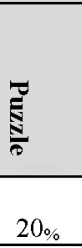 } & \multirow{2}{*}{ 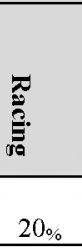 } & \multirow{2}{*}{ 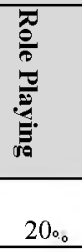 } & \multirow{2}{*}{$\begin{array}{l}\frac{2}{9} \\
20 \% \\
\end{array}$} & \multirow{2}{*}{$\frac{n}{20 \%}$} & \multirow{2}{*}{ 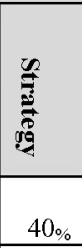 } & \multirow{2}{*}{$20 \%$} & \multirow{2}{*}{ 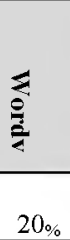 } \\
\hline & Player & & & & & & & & & & & & & & & & & \\
\hline \multirow{7}{*}{$\begin{array}{l}\text { Formal } \\
\text { Elemen }\end{array}$} & Objectives & $28 \%$ & $40 \%$ & 100 & $32 \%$ & $24 \%$ & $28 \%$ & $52 \%$ & $24 \%$ & $44 \%$ & $32 \%$ & $36 \%$ & $36 \%$ & $28 \%$ & $36 \%$ & $40 \%$ & $28 \%$ & $28 \%$ \\
\hline & Procedures & $28 \%$ & $36 \%$ & $280_{0}$ & $32 \%$ & $48 \%$ & $28 \%$ & $40_{\%}$ & $28 \%$ & $28 \%$ & $88 \%$ & $32 \%_{0}$ & $24 \%$ 。 & $25 \%$ & $36 \%$ & $32 \%$ & $36 \%$ & $28 \%$ \\
\hline & Rules & $40 \%$ & $40 \%$ & $280_{0}$ & $92 \%$ & $80 \%$ & $88 \%$ & $28 \%$ & $28 \%$ & $36 \%$ & $40 \%$ & $40 \%$ & $24 \%$ 。 & $24 \%$ & $84 \%$ & $28 \%$ & $40 \%$ & $36 \%$ \\
\hline & Resource & $36 \%$ & $36 \%$ & $36 \%$ & $24 \%$ & $28 \%$ & $36 \%$ & $36 \%$ & $84 \%$ & $24 \%$ & $32 \%$ & $80 \%$ & $40 \%$ 。 & $36 \%$ & $36 \%$ & $100 \%$ & $20 \%$ & $36 \%$ \\
\hline & Conflict & $40 \%$ & $40 \%$ & $360_{0}$ & $20 \%$ & $28 \%$ & $44 \%$ & $24 \%$ & $24 \%$ & $36 \%$ & $24 \%$ & $32 \%$ & $400_{0}$ & $28 \%$ & $36 \%$ & $200_{0}$ & $48 \%$ & $28 \%_{0}$ \\
\hline & Boundaries & $48 \%$ & $92 \%$ & $40 \%$ & $40 \%$ & $20 \%$ & $28 \%$ & $48 \%$ & $28 \%$ & $28 \%$ & $28 \%$ & $20 \%$ & $88 \%$ & $96 \%$ & $20 \%$ & $60 \%$ & $20 \%$ & $28 \%$ 。 \\
\hline & Outcome & $44 \%$ & $28 \%$ & 100 & $20 \%$ & $20 \%$ & $24 \%$ & $28 \%$ & $24 \%$ & $48 \%$ & $36 \%$ & $36 \%$ & $20 \%$ & $36 \%$ & $20 \%$ & $240 \%$ & $28 \%$ & $32 \%$ \\
\hline \multirow{7}{*}{$\begin{array}{l}\text { Dramatic } \\
\text { Elemen }\end{array}$} & Challenge & $92 \%$ & $36 \%$ & $100_{0}$ & $52 \%$ & $48 \%$ & $44 \%$ & $100 \%$ & $32 \%$ & $92 \%$ & $92 \%_{6}$ & $80 \%$ & $72 \sigma_{0}$ & $28 \%$ & $84 \%$ & $40 \%$ & $52 \%$ & $84 \%$ \\
\hline & Play & $20 \%$ & $20 \%$ & $20 \%$ 。 & $36 \%$ & $24 \%$ & $20 \%$ & $20 \%$ & $20 \%$ & $20 \%$ & $28 \%$ & $20 \%$ & $36 \%$ & $24 \%$ & $20 \%$ & $20 \%$ & $20 \%$ & $20 \%$ \\
\hline & Premise & $44 \%$ & $32 \%$ & $360_{\circ}$ & $20 \%$ & $20 \%$ & $20 \%$ & $24 \%$ & $20 \%$ & $20 \%$ & $20 \%$ & $24 \%$ & 280 & $36 \%$ & $28 \%$ & $20 \%$ & $20 \%$ & $24 \%$ \\
\hline & Character & $84 \%$ & $20 \%$ & $24 \%_{0}$ & $20 \%$ & $20 \%$ & $20 \%$ & $40 \%$ & $28 \%$ & $28 \%$ & $20 \%$ & $20 \%$ & $280_{0}$ & $20 \%$ & $36 \%$ & $20 \%$ & $20 \%$ & $200_{0}$ \\
\hline & Story & $28 \%$ & $96 \%$ & 280. & $20 \%$ & $20 \%$ & $20 \%$ & $16 \%$ & $24 \%$ & $20 \%$ & $20 \%$ & $36 \%$ & $92 \%$ & $32 \%$ & $20 \%$ & $32 \%$ & $36 \%$ & $20 \%$ \\
\hline & Worldbuilding & $36 \%$ & $100 \%$ & $36 \%$ & $20 \%$ & $20 \%$ & $20 \%$ & $32 \%$ & $24 \%$ & $20 \%$ & $20 \%$ & $36 \%$ & 100 & $32 \%$ & $20 \%$ & $92 \%$ & $20 \%$ & $20 \%$ \\
\hline & Dramatic Arc & 640, & $56 \%$ & 240. & $200_{0}$ & $20 \%$ & $200_{0}$ & $280_{0}$ & $20 \%$ & $200_{0}$ & $20 \%$ & $20 \%$ & 960. & $20 \%$ & $20 \%$ & $44 \%$ & $200_{0}$ & $20_{\%}$ \\
\hline
\end{tabular}




\section{Hasil dan Pembahasan}

\subsection{Pemetaan unsur elemen}

Grafik performa prosentase setiap unsur elemen tracy terhadap genre game google playstore berdasarkan Tabel 4 sebagai berikut :

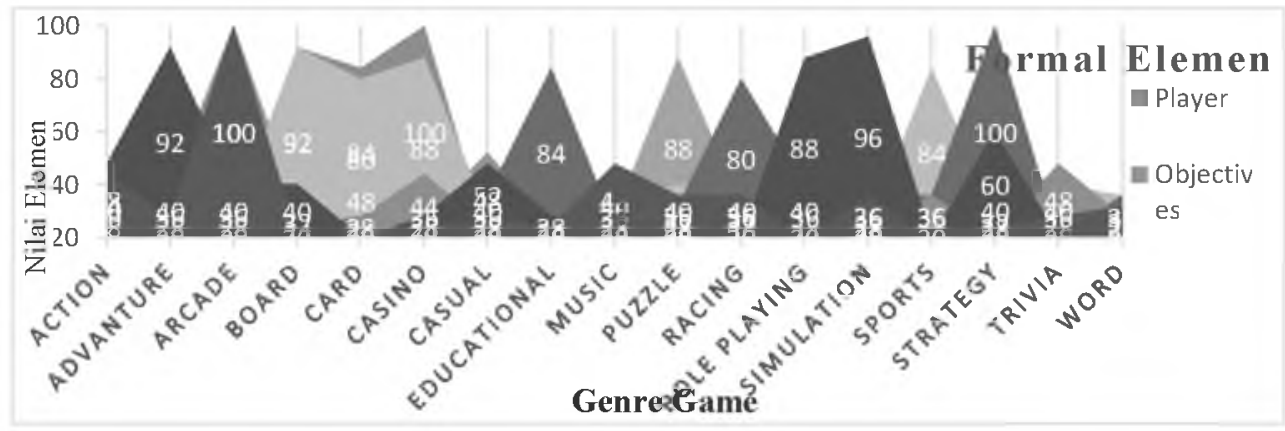

Gambar 1 Grafik performa Formal elemen terhadap semua genre game

Dalam Gambar 1 terdapat beberapa genre game yang memiliki unsur yang menonjol atau dominan dalam formal elemen, diantaranya yaitu :

1. Unsur Player paling dominan terdapat pada Board, Card, dan Casino

2. Unsur Objectives paling dominan adalah Arcade

3. Unsur Procedures paling dominan adalah Puzzle

4. Unsur Rules paling dominan pada adalah Board, Card, Casino, dan Sport

5. Unsur Resource paling dominan pada Educational, Racing, dan Strategy

6. Unsur Conflict pada Genre Google Playstore tidak terdapat game yang dominan

7. Unsur Boundaries paling dominan terdapat pada genre Advanture, Roleplaying, dan Simulation

8. Unsur Outcome paling dominan adalah Arcade.

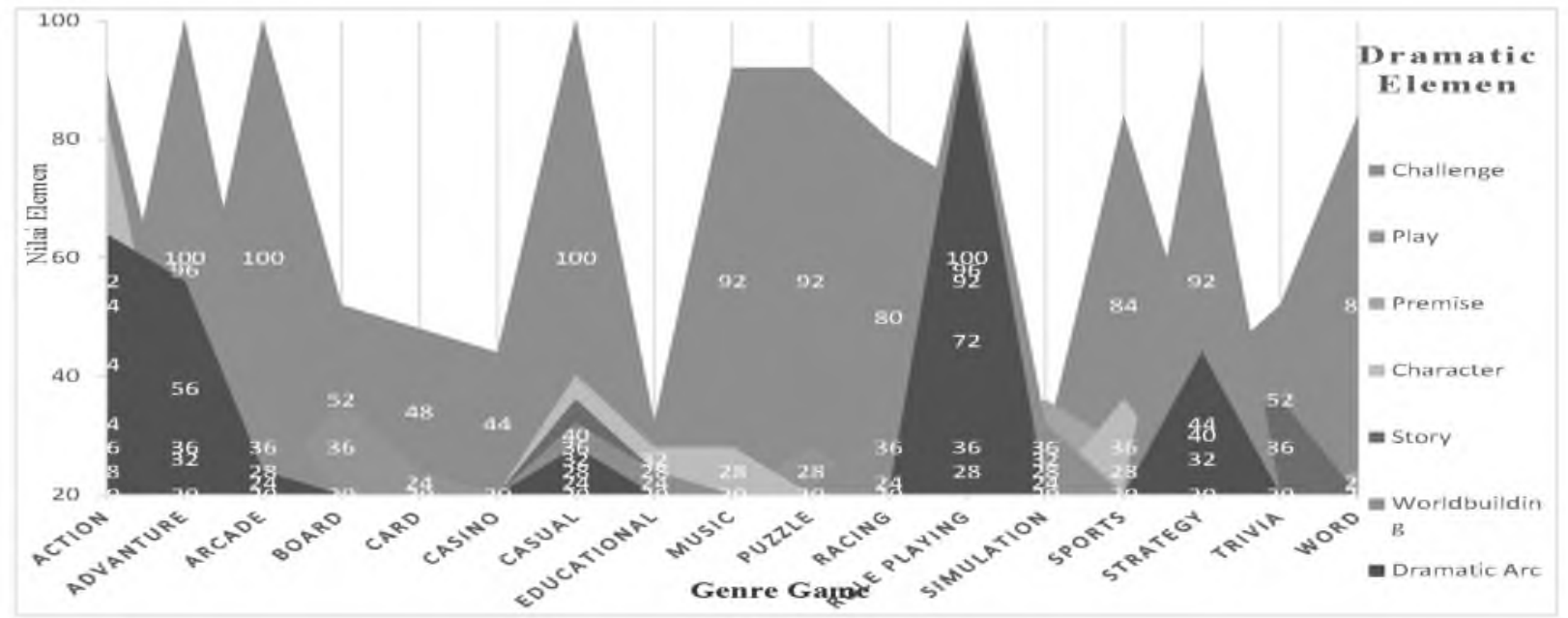

Gambar 2 Grafik performa Dramatic elemen terhadap semua genre game 
Dalam Gambar 2 terdapat beberapa genre game yang memiliki unsur yang menonjol atau dominan dalam Dramatic elemen, diantaranya yaitu :

1. Unsur Challenge terkuat pada genre Google Playstore ditemukan 8 dari 17 genre yang ada.

2. Unsur Play tidak ditemukan yang paling dominan selama pengujian Genre Google Playstore

3. Unsur Premise terkuat tidak ditemukan dalam Genre Google Playstore.

4. Unsur Character terkuat yang ada adalah Action

5. Unsur Story terkuat adalah Advanture dan Role Playing.

6. Unsur World Building terkuat adalah Advanture, Role Playing, dan Strategy

7. Unsur Dramatic Arc terkuat adalah Advanture dan Role Playing.

\subsection{Uji Kelayakan Proses pengujian}

Uji kelayakan yang dilakukan untuk mengetahui hasil pengujian pada Tabel 4, Gambar 1, dan Gambar 2. Pada penelitian ini akan menggunakan selected sample dan menggunakan teknik pengambilan sampel dengan pertimbangan tertentu yang disebut dengan teknik sampling purposive (Sugiyono, 2012). Roscoe (1975) dalam Sekaran (2006) memberikan salah satu acuan dalam pengambilan sampel yang dapat digunakan untuk penelitian. Pada penelitian ini, peneliti akan menggunakan 6 sample kuat yang memiliki kriteria dan berpengaruh besar terhadap dunia game, diantaranya yaitu Ahli/Pakar dibidang game, Developer/pengembang game, dan desainer/perancang game yang sudah memiliki kompeten di bidang masing masing.

Tabel 5. Tabel Uji kelayakan responden

\begin{tabular}{|c|c|c|c|c|c|c|c|c|}
\hline \multirow{2}{*}{$\begin{array}{c}\text { Nomor } \\
\text { Pertanyaan }\end{array}$} & \multicolumn{6}{|c|}{ Nilai dari Responden } & \multirow[b]{2}{*}{ Total } & \multirow{2}{*}{$\begin{array}{l}\text { Rata } \\
\text { rata }\end{array}$} \\
\hline & Ahli I & Ahli II & $\begin{array}{c}\text { Developer } \\
\text { I }\end{array}$ & $\begin{array}{l}\text { Developer } \\
\text { II }\end{array}$ & $\begin{array}{c}\text { Desainer } \\
\text { I } \\
\end{array}$ & $\begin{array}{c}\text { Desainer } \\
\text { II }\end{array}$ & & \\
\hline 1 & 5 & 4 & 4 & 4 & 4 & 4 & 25 & 4,17 \\
\hline 2 & 4 & 3 & 2 & 3 & 3 & 4 & 19 & 3,17 \\
\hline 3 & 5 & 4 & 4 & 5 & 5 & 5 & 28 & 4,67 \\
\hline 4 & 5 & 5 & 4 & 4 & 4 & 5 & 27 & 4,5 \\
\hline 5 & 5 & 5 & 4 & 3 & 3 & 4 & 24 & 4 \\
\hline 6 & 4 & 4 & 3 & 3 & 4 & 4 & 22 & 3,67 \\
\hline 7 & 5 & 5 & 4 & 4 & 5 & 5 & 28 & 4,67 \\
\hline 8 & 4 & 4 & 4 & 3 & 3 & 3 & 21 & 3,5 \\
\hline 9 & 5 & 5 & 5 & 4 & 4 & 5 & 28 & 4,67 \\
\hline 10 & 5 & 4 & 4 & 3 & 4 & 5 & 25 & 4,16 \\
\hline 11 & 2 & 3 & 4 & 5 & 4 & 4 & 22 & 3,67 \\
\hline 12 & 5 & 4 & 4 & 4 & 3 & 5 & 25 & 4,17 \\
\hline 13 & 5 & 5 & 5 & 4 & 5 & 5 & 29 & 4,83 \\
\hline 14 & 5 & 5 & 4 & 4 & 4 & 5 & 27 & 4,5 \\
\hline 15 & 4 & 5 & 4 & 4 & 5 & 5 & 27 & 4,5 \\
\hline Total (f) & 67 & 65 & 59 & 57 & 60 & 68 & 377 & 62,83 \\
\hline Rata-rata & 4,53 & 4,33 & 3,93 & 3,8 & 4,0 & 4,53 & 25,13 & 4,18 \\
\hline
\end{tabular}

Setiap responden yang diuji telah memiliki skala pengalaman dan terkualifikasi dalam bidangnya masing-masing. Tahap selanjutnya menelaah setiap pertanyaan dengan parameter tracy yang dilakukan, sebagai contoh pertanyaan nomor 1 mewakili unsur Player, dan seterusnya. 
Tabel 6. Tabel Prosentase unsur elemen Tracy Fullerton

\begin{tabular}{|c|c|c|c|c|}
\hline $\begin{array}{c}\text { Nomor } \\
\text { Pertanyaan }\end{array}$ & $\begin{array}{c}\text { Parameter } \\
\text { Tracy Fullerton }\end{array}$ & Total Nilai & Rata rata & Prosentase \\
\hline 1 & Player & 25 & 4.16 & $83.2 \%$ \\
\hline 2 & Objectives & 18 & 3 & $60 \%$ \\
\hline 3 & Procedures & 27 & 4.5 & $90 \%$ \\
\hline 4 & Rules & 27 & 4.5 & $90 \%$ \\
\hline 5 & Resources & 24 & 4 & $80 \%$ \\
\hline 6 & Conflict & 21 & 3.5 & $70 \%$ \\
\hline 7 & Boundaries & 28 & 4.67 & $93,4 \%$ \\
\hline 8 & Outcome & 22 & 3.67 & $73,4 \%$ \\
\hline 9 & Challenge & 28 & 4.67 & $93,4 \%$ \\
\hline 10 & Play & 25 & 4.16 & $83,2 \%$ \\
\hline 11 & Premise & 24 & 4 & $80 \%$ \\
\hline 12 & Character & 25 & 4.16 & $83,2 \%$ \\
\hline 13 & Story & 29 & 4.83 & $96,6 \%$ \\
\hline 14 & World Building & 27 & 4.5 & $90 \%$ \\
\hline 15 & The Dramatic Arc & 28 & 4.67 & $83,4 \%$ \\
\hline
\end{tabular}

Dari 15 pertanyaan yang masing masing mewakili 15 unsur elemen Tracy Fullerton yang telah diuji oleh 6 responden, dapat di simpulkan dari penggabungan Tabel 6 dengan tabel inverval tingkat intensitas pada 1 yaitu sebagai berikut:

Tabel 7. Kelayakan setiap unsur dinilai dari skala likert

\begin{tabular}{|c|c|c|}
\hline Interval Tingkat Intensitas & Kriteria & Jumlah Pertanyaan / Unsur elemen \\
\hline $0 \%-20 \%$ & Sangat Tidak Setuju & 0 \\
\hline $21 \%-40 \%$ & Tidak Setuju & 0 \\
\hline $41 \%-60 \%$ & Cukup Setuju & 1 \\
\hline $61 \%-80 \%$ & Setuju & 5 \\
\hline $81 \%-100 \%$ & Sangat Setuju & 9 \\
\hline
\end{tabular}

\subsection{Hasil Pengujian}

Hasil pengujian pada penelitian ini terbagi menjadi dua, yang pertama ada hasil pengujian dari peneliti terdapat hasil pada gambar 1 dan gambar 2 dimana setiap elemen pada parameter Tracy Fullerton memiliki kuantitas yang berbeda beda pada setiap genre game yang terdapat pada Google Playstore.

Hasil pengujian dari peneliti kemudian dijustifikasi terhadap 6 pakar dimana ditemukan kesimpulan pada tabel 7 yang menunjukan tidak ditemukan unsur elemen yang memiliki intensitas $0 \%-20 \%$ dan $21-40 \%$, terdapat 1 unsur elemen yang memiliki intensitas $41 \%-60 \%$ dengan kriteria cukup setuju, terdapat 5 unsur elemen yang memiliki intensitas $61 \%-80 \%$ dengan kriteria setuju, dan terdapat 9 unsur elemen yang memiliki intensitas $81 \%-100 \%$ yang menunjukan kriteria sangat setuju. 


\section{Kesimpulan \& Saran}

\subsection{Kesimpulan}

Berdasarkan hasil analisis dan tahapan penggunaan parameter Tracy Fullerton yang telah diujikan terhadap respon, sehingga dapat disimpulkan sebagai berikut :

1. Dalam pengujian yang dilakukan terhadap 15 unsur elemen yang ada dalam parameter tracy fullerton, dapat ditemukan 12 unsur elemen yang memiliki unsur dominan pada setiap genre game. Sedangkan 3 unsur lainya tidak ditemukan dominan pada genre yang diuji.

2. Penelitian ini berhasil menentukan nilai variable elemen pada setiap parameter Tracy Fullerton yaitu jika unsur tersebut ada dan semakin banyak maka variable nilai semakin tinggi, sedangkan apabila sedikit atau bahkan tidak ada maka nilai variable semakin kecil sehingga mempermudah responden dalam menganalisa setiap elemen, dimana terdapat 1 unsur dalam interval $41 \%-60 \%$ yang menyatakan cukup setuju. Terdapat 5 unsur dalam interval $61 \%-80 \%$ yang menyatakan setuju. Dan terdapat 9 unsur dalam interval $81 \%-100 \%$ yang menyatakan sangat setuju.

3. Parameter yang ada pada Tracy Fullerton dapat diterapkan sebagai penentu elemen dominan / terkuat dalam menentukan perbedaan pada setiap genre yang ada pada Google Playstore, serta dilakukan pengujian dengan metode skala Likert sehingga didapatkan hasil kesimpulan sebagai berikut : Ahli Game $88,67 \%=$ Sangat Tepat, Developer Game $77,33 \%=$ Tepat, Desainer Game $85,3 \%=$ sangat tepat. Penggabungan ketiga sumber responden tersebut adalah $83.7 \%$.hasil dari uji kelayakan tersebut menunjukkan bahwa nilai dari masing-masing instrumen mencapai nilai di atas $81 \%$ sehingga dapat disimpulkan bahwa sangat tepat atau layak untuk diterapkan.

\subsection{Saran}

Menyimpulkan hasil kritik saran dari responden dan peneliti yaitu melakukan perbaharuan penelitian diantaranya membuat model pengujian dari platform lain bisa dari Appstore (Apple) maupun platform console atau PC (Personal Computer). Selain itu mencoba melakukan justifikasi terhadap para pengguna android yang memiliki game didalamnya, sehingga dimungkinkan akan menemukan perbedaan baik dari hasil pengujian dan justifikasi dalam menilai sebuah game. 


\section{Daftar Pustaka}

Adam, Ernest. 2010. Fundamentals of Game Design Second Edition. Berkeley: New Riders Games

Arifianto, Teguh. 2011. Membuat Interface Aplikasi Android Lebih Keren dengan LWUIT. Yogyakarta: Andi Publisher

Dawes, John 2008, "Do Data Characteristics Change According to the number of scale points used? An experiment using 5-point, 7-point and 10-point scales," International Journal of Market Research, 50 (1), 61-77.

Dillon, Teresa 2005. Advanture Games for Learning and Storytelling. UK, Futurelab Prototype Context Paper, Adventure Author

Fullerton, T. 2014. Game Design Workshop: A Playcentric Approach to Creating Innovative Games (Third ed.). Florida: CRC Press

Koster, R.2005. Theory of Fun for Game Design. California: O'Reilly Media

Likert, Rensis.1932. "A Technique for the Measurement of Attitudes", Archives of Psychology 140: 1-55

Rouse, R. 2005.Game Design: Theory \& Practice. Texas: Wordware Publisihing

Schell, J.2008. Art Of Game Design, ISBN:978-a-12-36949-6:Elsevier Inc.

Statista.2018. Global Reach Popular Android Game Genres. (akses 6-3-2018)

Sugiyono.2015.Metode Penelitian Manajemen, Alfabeta, Bandung.

Tondello, F. Gustavo., Lennart E. Nacke.2017. Applying Gameful Design Heuristics. ACM 978-1-4503-4656-6/17/05. 